\title{
Green synthesis, characterization, and electrochemical behavior of gold nanoparticles on boron-doped diamond electrode
}

\author{
Wiyogo Prio Wicaksono*, Aushofin Hamidah \\ Department of Chemistry, Universitas Islam Indonesia, Jl. Kaliurang KM 14.5 Yogyakarta 55584, Indonesia \\ ${ }^{*}$ Corresponding author. Email address: wiyogo.prio@uii.ac.id
}

Received July 18, 2017; Accepted December 14, 2017

\begin{abstract}
Gold nanoparticles (AuNPs) have been successfully synthesized through a single-step bioreduction method using Piper betle leaf extract (PBLE) as a green reducing and stabilizing agent. Their formation was confirmed by UV-Visible spectroscopy, resulted in a characteristic Surface Plasmon Resonance (SPR) peak at $545 \mathrm{~nm}$, whereas there is no peak observed in the extract. By using Particle Size Analyzer (PSA), it has been characterized that they have a $\sim 100$ $\mathrm{nm}$ diameter. For characterizing electrochemical behavior, the cyclic voltammetry technique was applied in a various range of electrolyte condition $(\mathrm{HCl} 0.1 \mathrm{M}, \mathrm{NaCl} 0.1 \mathrm{M}$, phosphate buffer $0.1 \mathrm{M} \mathrm{pH} 7$, and $\mathrm{NaOH} 0.1 \mathrm{M}$ ). The best oxidation and reduction peak of the AuNPs were obtained in $\mathrm{HCl}$ at $0.93 \mathrm{~V}$ and $0.68 \mathrm{~V}$, respectively. This green synthesized AuNPs could be applied as a label in immunochromatographic strip tests for various sensing applications.
\end{abstract}

Key words: green synthesis; piper betle leaf extract; gold nanoparticles; electrochemical behavior; boron-doped diamond electrode

\section{ABSTRAK}

Nanopartikel emas telah berhasil disintesis melalui metode bioreduksi satu tahap menggunakan ekstrak daun sirih sebagai agen pereduksi dan penstabil. Terbentuknya nanopartikel emas tersebut dikonfirmasi dengan spektroskopi UV-Visibel menghasilkan karakteristik puncak Surface Plasmon Resonance (SPR) pada panjang gelombang $545 \mathrm{~nm}$, sementara ekstraknya tidak teramati. Berdasarkan karakterisasi menggunakan Particle Size Analyzer (PSA) diperoleh informasi nanopartikel emas tersebut memiliki diameter $\sim 100 \mathrm{~nm}$. Perilaku elektrokimia pada berbagai kondisi elektrolit $(\mathrm{HCl} 0,1 \mathrm{M}, \mathrm{NaCl} 0,1 \mathrm{M}$, buffer fosfat $0,1 \mathrm{M} \mathrm{pH} 7$, dan $\mathrm{NaOH} 0,1 \mathrm{M})$ dinvestigasi menggunakan teknik voltametri siklik. Puncak oksidasi dan reduksi terbaik dari nanopartikel emas dapat diamati menggunakan larutan elektrolit $\mathrm{HCl}$ pada potensial 0,93 $\mathrm{V}$ dan $0,68 \mathrm{~V}$, secara berurutan. Nanopartikel emas yang telah disintesis ini dapat digunakan sebagai label pada tes strip immunokromatografi untuk berbagai aplikasi sensor.

Kata kunci: sintesis hijau; ekstrak daun sirih; nanopartikel emas; perilaku elektrokimia; elektroda boron-doped diamond

\section{INTRODUCTION}

Gold nanoparticles (AuNPs) have attracted many researchers due to their unique catalytic, electrical, optical, and biocompatible properties [1-3]. These nanoparticles were widely used in medical [3], pharmacology [4], and sensing [2] applications. They also witnessed a good electrochemical performance as metal nanoparticle label immunochromatographic strip tests for quantitative detection of melamine [5]. To synthesize them, numerous methods have been utilized including green synthesis. It provides many advantages over chemical and physical methods because it is environmentally friendly, effective cost, low energy and temperature requirement, and less toxic [4]. As stated in a number of publications, plant extracts was generally applied in AuNPs synthesis [6]. One of potential materials as a reducing agent in their synthesis is Piper betle (PB) leaf which contains antioxidant and flavonoid compound. It is usually treated as a traditional medicine and its crop is extensively grown in several Asian countries [7].

Concerning AuNPs synthesis, this work reports the use of a simple and green synthesis method using Piper betle leaf extract (PBLE) as their reducing agent. The investigation of its electrochemical behavior in various supporting electrolytes was on Boron-Doped Diamond (BDD) electrode to study their capacity as labeling agent in electrochemical immunochromatographic strip test for various sensing applications.

\section{EXPERIMENTAL SECTION Materials}

Chloroauric acid $\left(\mathrm{HAuCl}_{4}\right)$ was purchased from Wako Pure Chemical Industries Ltd (Japan), while sodium chloride $(\mathrm{NaCl})$, sodium hydroxide $(\mathrm{NaOH})$, 
sodium hydrogen phosphate $\left(\mathrm{Na}_{2} \mathrm{HPO}_{4}\right)$, sodium dihydrogen phosphate $\left(\mathrm{NaH}_{2} \mathrm{PO}_{4}\right)$, and hydrochloric acid $(\mathrm{HCl})$ were supplied by Merck Chemicals. All of these chemicals were used directly without any pretreatment. Fresh PB leaves were purchased from the traditional market in Yogyakarta, Indonesia.

\section{Procedure \\ Preparation of the leaf extract}

The leaf extract was prepared from $1 \mathrm{~g}$ of fresh PB leaves chopped into small piece, crushed, then diluted in $100 \mathrm{~mL}$ deionized water by a stirring for $4 \mathrm{~h}$. The leaf extract was then filtered and readily used for the NPs synthesis.

\section{Synthesis and characterization of gold nanoparticles}

The synthesis of AuNPs was prepared using a single-step reduction method [8]. Briefly, a $40 \mathrm{~mL}$ of $\mathrm{HAuCl}_{4}(0.5 \mathrm{mM})$ was prepared. A $20 \mathrm{~mL}$ of leaf extract was then added to the solution followed by a vigorous stirring for $2 \mathrm{~h}$. The formation of AuNPs can be indicated by the change of solution color to be a typical dark-red solution. The color was characterized using UV-Visible Spectrophotometer (Hitachi 5300) and the diameter of AuNPs was characterized using Particle Size Analyzer (PSA, Horiba Scientific SZ -100).

\section{Electrochemical Behavior}

To characterize AuNPs electrochemical behaviour, this study applied Potentiostats ( $\mu$ Autolab type III Metrohm) in a three-electrode system cell. BDD was used as the working electrode, while a platinum plate and an $\mathrm{Ag} / \mathrm{AgCl}$ system were used as the counter and the reference electrode, respectively. Evaluation of their electrochemical behavior used several solutions $(\mathrm{HCl}$ $0.1 \mathrm{M}, \mathrm{NaCl} 0.1 \mathrm{M}$, phosphate buffer $0.1 \mathrm{M} \mathrm{pH} \mathrm{7,} \mathrm{and}$ $\mathrm{NaOH} 0.1 \mathrm{M}$ ) as the supporting electrolytes.

\section{RESULTS AND DISCUSSION}

\section{UV-Visible and PSA Study}

Figure 1 depicts a characteristic Surface Plasmon Resonance (SPR) peak at $545 \mathrm{~nm}$, indicating the successful formation of AuNPs [9], whereas there was no peak observed in the extract. It is concluded that PBLE contributes effectively to the synthesis. The reduction of gold (from $\mathrm{Au}^{3+}$ to $\mathrm{Au}$ ) could occur as consequence of hydroxyl group oxidation to a carbonyl group of the reducing agent as follow [7]:

$$
\mathrm{AuCl}_{4}^{-}+3 \mathrm{R}-\mathrm{OH} \rightarrow \mathrm{Au}^{0}+3 \mathrm{R}=\mathrm{O}+3 \mathrm{H}^{+}+4 \mathrm{Cl}^{-}
$$

Particle size study was conducted to evaluate the particle size distribution of the AuNPs. Figure 2 shows that most of the synthesized AuNPs have a diameter $\sim 100 \mathrm{~nm}$. This result revealed that PB leaf could be used effectively to synthesize nanomaterial in room condition proper to a report [10] that synthesized AuNPs by seed-mediated growth method at room temperature produced the particles that have diameter varying from 20-110 nm. The big particles might be produced because of slow stirring along the synthesis. A proper speed of stirring process in the AuNPs synthesis will produce a small and uniform size of AuNPs [11].

\section{Electrochemical Behavior Study}

To investigate the electrochemical behavior of the synthesized AuNPs, cyclic voltammetry was performed. Several supporting electrolyte solutions were used to obtain the best condition of AuNPs activity. Cyclic voltammograms (CVs) of AuNPs in four different supporting electrolytes are shown in Figure 3 . Figure 3 (a) shows in $\mathrm{HCl}$ supporting electrolyte, an oxidation and reduction peak are observed at $0.93 \mathrm{~V}$ and $0.68 \mathrm{~V}$, respectively. This result has a similar electrochemical characteristic with the AuNPs which is synthesized using pure chemical grade, trisodium citrate, both as reducing and capping agent [5]. Figure 3 (b) (c), and (d) depicts electrochemical behavior in higher $\mathrm{pH}$ condition, $\mathrm{NaCl}$ and phosphate buffer $\mathrm{pH} 7$ (neutral), and $\mathrm{NaOH}$ (base condition). We could see a weak oxidation peak of AuNPs and the peak had shifted to lower potential as increasing the $\mathrm{pH}$ condition. The result is in agreement with the potentials-pH equilibrium diagram of gold as reported before [12]. The comparison of electrochemical behavior in various supporting electrolytes is shown in Figure 4. The typical CVs refer to oxidation and reduction reaction of AuNPs in various supporting electrolytes as follows [13]:

\section{Oxidation: $\quad 2 \mathrm{Au}+3 \mathrm{H}_{2} \mathrm{O} \rightarrow \mathrm{Au}_{2} \mathrm{O}_{3}+6 \mathrm{H}^{+}+6 \mathrm{e}$ Reduction: $\quad \mathrm{Au}_{2} \mathrm{O}_{3}+6 \mathrm{H}^{+}+6 \mathrm{e} \rightarrow 2 \mathrm{Au}+3 \mathrm{H}_{2} \mathrm{O}$}

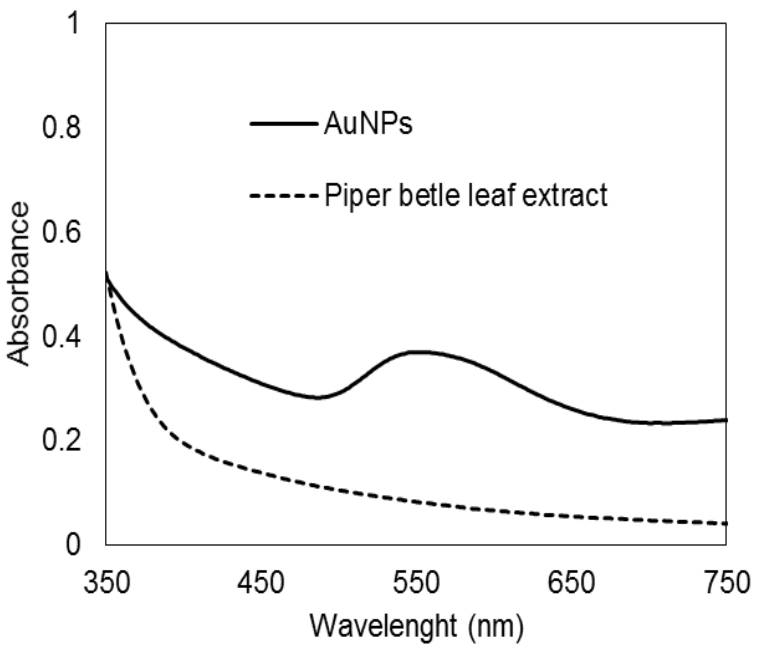

Figure 1 UV-Visible spectra of AuNPs and Piper betle leaf extract solution 
Acta. Chim. Asiana., 2018, 1 (1), 1 - 5

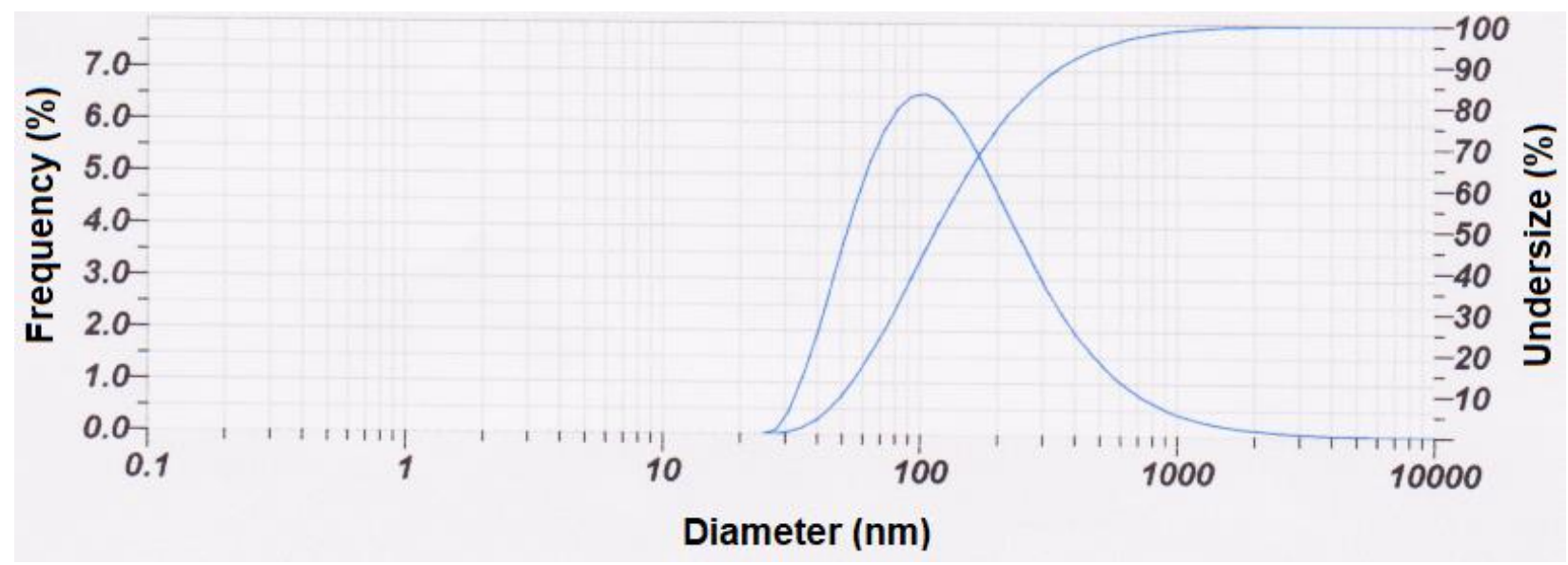

Figure 2 Particle size distributions of the AuNPs
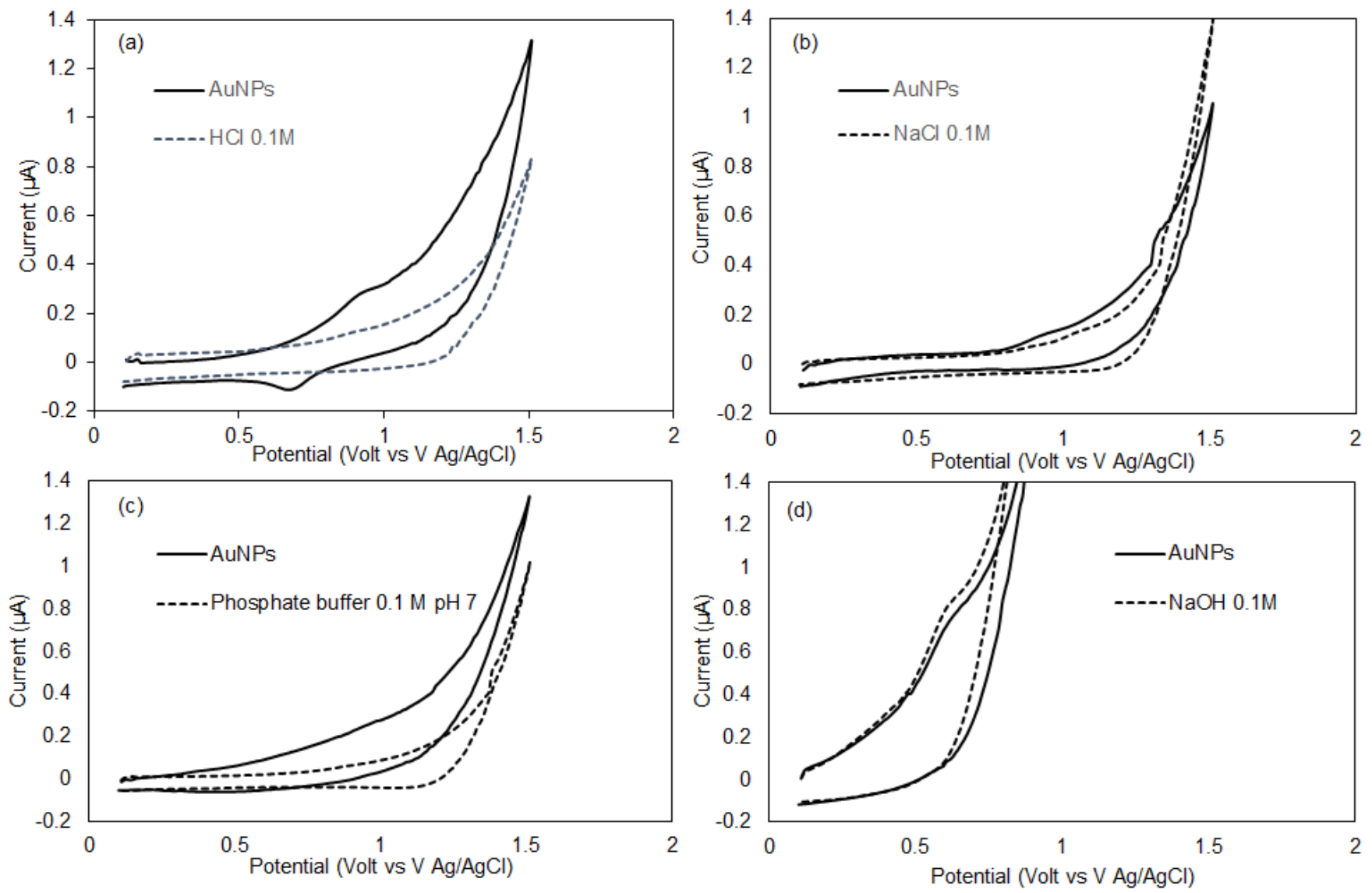

Figure $3 \mathrm{CVs}$ of AuNPs: (a) recorded in $\mathrm{HCl} 0.1 \mathrm{M}$ at $100 \mathrm{mV} / \mathrm{s}$ and its background ;(b) recorded in $\mathrm{NaCl} 0.1 \mathrm{M}$ at 100 $\mathrm{mV} / \mathrm{s}$ and its background; (c) recorded in buffer phosphate $0.1 \mathrm{M} \mathrm{pH} 7$ at $100 \mathrm{mV} / \mathrm{s}$ and its background ;(d) recorded in $\mathrm{NaOH} 0.1 \mathrm{M}$ at $100 \mathrm{mV} / \mathrm{s}$ and its background 


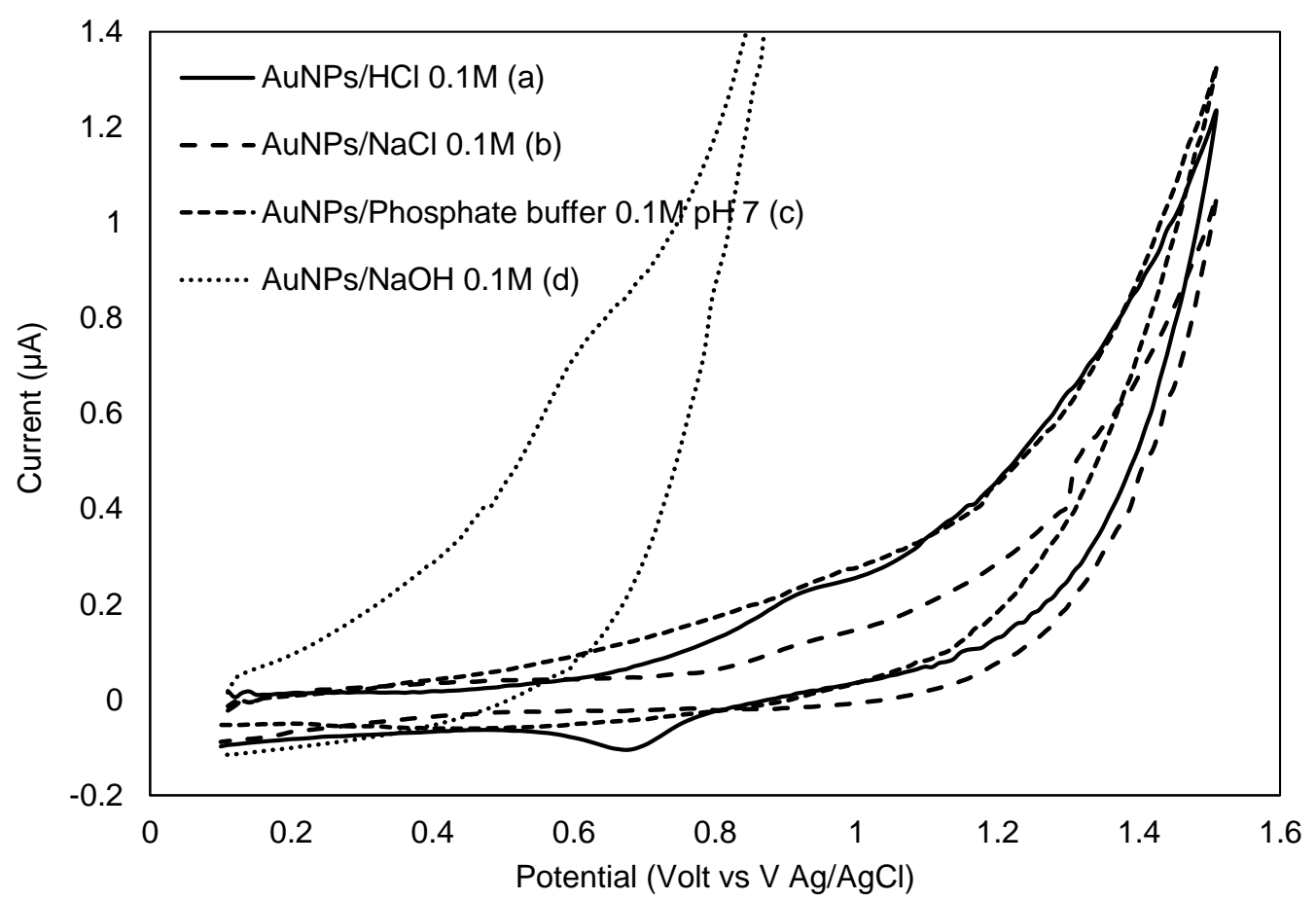

Figure 4 Comparison CVs of AuNPs in various supporting electrolyte $(\mathrm{HCl} 0.1 \mathrm{M}$, phosphate buffer $0.1 \mathrm{M} \mathrm{pH} 7, \mathrm{NaCl}$ $0.1 \mathrm{M}$, and $\mathrm{NaOH} 0.1 \mathrm{M}$ ) recorded at $100 \mathrm{mV} / \mathrm{s}$

\section{CONCLUSION}

Gold nanoparticles (AuNPs) have been successfully synthesized by a very simple single-step reduction method using PBLE aqueous solution with affordable reducing and stabilizing agent. From electrochemical study, the best activity of AuNPs is in $\mathrm{HCl} 0.1 \mathrm{M}$ with the oxidation and reduction peak at 0.93 $\mathrm{V}$ and $0.68 \mathrm{~V}$, respectively. This result shows synthesized AuNPs has no significantly different electrochemical behavior compared to pure chemical grade one. Thus, they have potential to use as a label in electrochemical immunochromatographic strip test for sensing applications.

\section{ACKNOWLEDGEMENTS}

This research was funded by Hibah Penelitian Pemula DPPM Universitas Islam Indonesia Tahun 2016, Contract No.090/Dir/DPPM/70/Pen.Pemula/PII/VIII/2016.

\section{REFERENCES}

1. Kasthuri, J., Kathiravan, K., \& Rajendiran, N. (2009). Phyllanthin-assisted biosynthesis of silver and gold nanoparticles: a novel biological approach. Journal of Nanoparticle Research, 11(5), 1075-1085..

2. Das, M., Shim, K. H., An, S. S. A., \& Yi, D. K. (2011). Review on gold nanoparticles and their applications. Toxicology and Environmental Health Sciences, 3(4), 193-205.

3. Connor, E. E., Mwamuka, J., Gole, A., Murphy, C. J., \& Wyatt, M. D. (2005). Gold nanoparticles are taken up by human cells but do not cause acute cytotoxicity. Small, 1(3), 325-327.

4. Jayaseelan, C., Ramkumar, R., Rahuman, A. A., \& Perumal, P. (2013). Green synthesis of gold nanoparticles using seed aqueous extract of Abelmoschus esculentus and its antifungal activity. industrial crops and products, 45, 423-429.

5. Ivandini, T. A., Wicaksono, W. P., Saepudin, E., Rismetov, B., \& Einaga, Y. (2015). Anodic stripping voltammetry of gold nanoparticles at boron-doped diamond electrodes and its application in immunochromatographic strip tests. Talanta, 134, 136-143.

6. Sujitha, M. V., \& Kannan, S. (2013). Green synthesis of gold nanoparticles using Citrus fruits (Citrus limon, Citrus reticulata and Citrus sinensis) aqueous extract and its characterization. Spectrochimica Acta Part A: Molecular and Biomolecular Spectroscopy, 102, 1523.

7. Punuri, J. B., Sharma, P., Sibyala, S., Tamuli, R., \& Bora, U. (2012). Piper betle-mediated green synthesis of biocompatible gold nanoparticles. International Nano Letters, 2(1), 18.

8. Zhan, G., Huang, J., Du, M., Abdul-Rauf, I., Ma, Y., \& Li, Q. (2011). Green synthesis of Au-Pd bimetallic nanoparticles: Single-step bioreduction method with plant extract. Materials Letters, 65(19), 2989-2991.

9. Kimling, J., Maier, M., Okenve, B., Kotaidis, V., Ballot, H., \& Plech, A. (2006). Turkevich method for gold nanoparticle synthesis revisited. The Journal of Physical Chemistry B, 110(32), 15700-15707. 
10. Leng, W., Pati, P., \& Vikesland, P. J. (2015). Room temperature seed mediated growth of gold nanoparticles: mechanistic investigations and life cycle assesment. Environmental Science: Nano, 2(5), 440-453.

11. Huang, X., Li, Y., \& Zhong, X. (2014). Effect of experimental conditions on size control of $\mathrm{Au}$ nanoparticles synthesized by atmospheric microplasma electrochemistry. Nanoscale research letters, 9(1), 572.

12. Takeno, N. (2005). National Institute of Advanced Industrial Science and Technology. Atlas of Eh-pH diagrams. Geological Survey of Japan Open File Report. Takeno, Naoto. 1-285.

13. Pourbaix, M., 1974, atlas of electrochemical equilibria in aqueous solutions, NACE international, houston, 1-644. 